\title{
In-service training Program for Housekeepers Regarding Safe Health Care Waste Management at Main Assiut University Hospital
}

\author{
Nagwa Mohamed Gamal, Hoda Diab Fahmy \& Neama Mohamed Elmagraby.
}

1. Director of Continuous Education for nursing at Assiut University Hospital, Egypt.

2. Professor of Community Heath Nursing, Faculty of Nursing, Assiut University, Egypt.

3. Assist.Prof of Community Heath Nursing, Faculty of Nursing, Assiut University, Egypt.

\begin{abstract}
Background: Safe handling and secure storage of clinical waste in hospitals is an important part of good housekeeping and risk reduction. The study aimed: The effect of an in-service training program for housekeeper about safe health care waste management. Subjects and methods:Quazi experimental research design which were selected through convenient sample. The total number of housekeepers was 159 housekeepers who conducting in the following departments General and special surgical, Private departments, Separation waste rooms and Incineration were included in the study. Study tools: It include three different tools . first one is a structured interview questionnaire sheet which include, personal characteristics of studied subject. Second parts include housekeepers' knowledge about infection, and, waste management second tool is observation checklist and third tool is an attitude scale (pre, post \& follow tests) Results: The main results revealed that $47.8 \%$ was illiterate. While $95.6 \%$ had not attended training about waste management. Also $66.7 \%$ of housekeepers were exposed to needle stick. Housekeepers had satisfactory knowledge, adequate practices and positive attitude after implementing the trainining program. Recommendation: Periodic in-service training program and medical checkup for all housekeepers working in the hospital. Also implementation of immunization program.
\end{abstract}

\section{Keywords: Inservice Training Program, Housekeepers, Occupational Exposure, Safe handling \& Waste Management.}

\section{Introduction}

With the increasing of healthcare services and the number of people the volume of medical waste becomes voluminous, therefore, proper management is essential to maintain hygienic, aesthetics, cleanliness, and control of environmental pollution (Lugendo, 2016).

Medical waste is any solid or liquid waste generated during diagnosis treatment, immunization or during medical research. Medical waste includes biomedical waste, sharps, chemical, pharmaceutical, geotaxis, radioactive and heavy metals wastes .High-income countries can generate up to $6 \mathrm{~kg}$ of hazardous waste per person per year. In the majority of low-income countries, health-care waste is usually not separated into hazardous or nonhazardous waste. In these countries the total health-care waste per person per year is anywhere from 0.5 to $3 \mathrm{~kg}$. (Koren, 2017)

Hazardous waste founds $20 \%$ of hospital waste in Egypt. Biomedical waste in the shape of excised body organs, blood and body fluids contaminated cotton, bandage, and plaster casts forms (15\%).Sharps as used needles, syringes and scalpel constitute $(1 \%)$. Chemical and pharmaceutical waste present $(3 \%)$ while genotoxic, radioactive and heavy metals wastes present(1\%).Garbage and rubbish of the hospitals which are similar in nature to household trash and formed of food remnants, packaging materials, bottles and plastic containers constitute (80\%)of hospital waste in Egypt. Although they pose no risk of injury or infection, unfortunately, they are usually mixed with the hazardous waste and increase the volume of hazardous waste to entail all the hospital waste.( Lugendo,2016).

Analysis of the composition the infectious waste stream and better segregation of waste reduce the disposal costs and the load on the hospital incinerator. Also, it identifies the inappropriate items having significant cost or unsafe implications.(Hossain et al., 2011).

Egyptian national principles requires documented comprehensive policy of each hospital for its waste management, role description of the team, one responsible person, correct disposal of sharps in nonpenetrable container and disposal of medical wastes in red or yellow bags. Diseases of modern like hepatitis-B, AIDS are also drawing attention for proper management of hospital wastes as persons who are in touch of these materials during providing services including physicians are at the risk(Ioos et al., 2014)

Many workers especially at the beginning of their career are not aware of the proper management of the medical wastes. Therefore, they may not only harm themselves but they also share in dissemination of these hazardous wastes. (Jerie, 2016) 


\section{Significant of the study}

Hospitals setting are a prime location for the spread of infectious diseases (Landelle et al,2013).Improper management of medical waste may cause health hazards through transmission of diseases, not only health workers and their families, but to the patients and their relatives. According to my master thesis at main Assiut University hospital .It was found inadequate knowledge and poor practices related to safe handling of hospital wastes disposal and the housekeepers are the ones who are responsible for handling the disposal of waste and therefore they are exposed directly to these hazards. So the importance of proper waste management and the lack of sound system in their workplace are more needed. Therefore, I decided to developing and implementing in-service training program for housekeepers about the proper management and disposal of wastes to increase knowledge and improving their practices in handling of hazardous wastes.

\section{Aims of the study}

It aimed to plan, implement and evaluate an inservice training program for housekeeper about safe health care waste management.

\section{Research Hypothesis}

To fulfill the study, the following hypotheses are formulated

After implementation of in service training program, the knowledge, practices and attitude of housekeepers about safe health care waste management will be improved

\section{Subjects \& methods}

Design: Quasi-experimental research design was used in the current study

\section{Setting of the study}

The study was carried out in Main Assiut University Hospital at some different setting. General surgical departments, special surgical departments, Private departments, Separation waste rooms and Incineration .

Subjects Convenient sample was used in this study. The target selected populations in the current study are housekeepers who working in the most infectious and available areas within one year. The total number are (159) housekeepers divided to 26 housekeepers from general surgical department, 33 from private department ,9 from waste collection rooms ,7 housekeepers from incinerator and 84 housekeepers from special surgical.

\section{Tools}

Tool (1):An interview Questionaire

It consists two parts

Part (1): Personnel characteristics of study subjects it is designed to gather data about name, age, educational qualifications, years of experiences, unit of work, and attendance training courses. Part (2): It was included questions regarding knowledge about:

- Definition of Infection ,

- Nosocomial infection and knowledge about waste management as types of health care wastes ,

- Classification of hazardous waste, when wearing hard work gloves, deal with blood on the floor or on the wall and how deal with blood splash in eye/mouth from the patient. The sheet was administrated before implementation of the program, immediately after implementation of the program, and three months later for follow up.

Tool(2): Attitude Scale

Likert scale used to assess the attitude of housekeepers. This tool developed and translated by researchers in Arabic and it consists of 10 questions with positive and negative statements. The responses are three points "agree, uncertain, disagree". The form was filled out before implementation of the program, immediately after implementation, and follow up after three months later.

Tool (3): An observation checklist

This tool is based on (Asha et al,2016).

It consists of the following procedures: Housekeepers practices concerning handwashing, wearing Personnel protective equipment, Waste management (segregation, handling, Transportation, final disposal).How to dispose body substances, excretions and secretions.

\section{Field work}

Methods of data collection

Program construction: It included phases

Phase 1: Preparatory phase and administrative design:

An official approval was obtained from Dean of the Faculty of Nursing, Assiut University to the Director of the Main Assiut University Hospital to the head of departments, to carry out the study. The researcher explained the purpose of the study, and asked for a permission to conduct the study.

\section{Content validity and reliability}

It was established by a panel of 5 experts who revised the tools for clarity, relevance, applicability ,comprehensiveness, understanding and ease for implementation. According to their opinion minor modifications were applied.

Reliability: Reliability of tool I, tool II tool and tool III was assessed using cronbach alpha test to test the internal consistency Knowledge $=0.842$, Attitude $=0.793$ and Practices $=0.8543$.

Pilot Study

After developing the necessary tools of the study.

A pilot study that included 15 housekeepers $(10 \%)$ was carried out to ensure clarity and applicability of 
the developed tools and to estimate the time needed to fill The questionnaires. This sample was not included in the total study sample and the final forms of the tools were developed.

\section{Ethical consideration}

The purpose of this study was explained for every interviewed individualof the studied sample. Housekeepers have ethical rights to participate or refuse participation in the study; oral consent was taken from all Housekeepers who participated in the study to ensure active participation and cooperation during the implementation of the program and they were informed that the information obtained will be confidential and will be used only for the purpose of the study.

\section{Designing the program}

The researcher designed the proposed training program after literature review (nursing textbook, infection control guideline, journals, internet resources,paners, video films) about waste management and assessment of housekeepers knowledge, attitude and practice in this regrad.

\section{General objectives}

To improve knowledge , Attitude and practices of the housekeepers about safety environment in the hospital.

\section{Specific objectives}

By the end of this course, the participantswill be able to

- Define infection, hospital acquired infection, standardprecaution and waste.

- Recognize the Infection chain.

- List Standrad Precautions

- Discuss Methods of transmissiom of infection

- Illustrate Types of waste.

- Describe Stages of waste management

- Recognize Safety disposal of the wastes.

Regarding to: hazards of improper management of health care waste each participants can be able to

- List the types of hazards

- Identify persons at risk

- Explain the hazards from infectious waste, sharps, chemical and pharmaceutical, genotoxic and radioactive waste.

- Discuss Incidence report for needle stick

- Apply handwashing steps

- Apply how to deal with needlestick and splashes of secretion from the patient.

\section{Preparatory stage and administrative design}

An official approval was obtained from Dean of the Faculty of Nursing, Assiut University to the Director of the Main Assiut University Hospital to the head of departments, to carry out the study. The researchers explained the purpose of the study, and asking for permission to conduct the study.
Phase П: Implementation of the program

To facilitate the implementation of the training program about safe handling of waste management the researcher prepared the training Placesin which the implementation of the program was carried out like the units, waste rooms. Sometimes in the (continuing training and education center at the institute of nursing) and Incinerator outside the hospital.,

Methods of teaching

- Lectures.

- Small group discussions.

- Brain storming.

- Video Films

- PowerPoint

Teaching Aids Used

- Booklets were provided to all participants as handout.

- Paners.

This was followed by arranging for the training program schedule based on the contents of the program, the number of staff involved, the time availability, the shifts as well as resoureces available. The researcher explained the nature and purpose of training program and filled the Pretest before the application of the program to assess housekeepers, knowledge. Also, the researcher asked them about the next teaching session, as well as . choosing their optimal time for giving the training program whenever they have minimal workload.

The program has been finished by 159 housekeepers, who were divided into 35 groups plus 16 from waste rooms and incinrator who were divided two groups .Each group contained ( 3-4 ) housekeepers, and 2 groups each week were taken. The total number of sessions for each group were 3 sessions in the day for two days. Every group received 6 session a week,. The duration of each session ranged between 60-90 minutes .The sessions were given according to the previous program phases.Each session usually started by a summary of what has been taught during the previous sessions and the objectives of the new topics. Feedback and reinforcement of teaching were performed according to the housekeepers needs to ensure their understanding. Each housekeeper obtained a copy of the in-service educational training program booklet that included all the training contents as a handout.

Phase шI. Evaluation phase:

Immediately after of implementation program as well as after 3 months later, the housekeepers knowledge, attitude and practices has been evaluated by the researchers. They researcher observed the housekeepers continuously during actual work in the different units from the beginning of shift until its end. 


\section{Statistical Analysis}

Statistical analysis was done using SPSS 19.0 software packages statistical. Data were presented using descriptive statistics in the form of frequencies for qualitative variables and mean \pm standard deviations for quantitative variables. Qualitative variables were compared using chi-square test. Whenever the expected values in one or more of the cells in a $2 \times 2$ cells was less than 5 , Fiser exact test was used instead .Pearson correlation analysis was used for identify the relationships among quantitative variables.

\section{Results}

Table (1): Distribution of housekeepers regarding their personal characteristics at Main Assiut University Hospital (N=159).

\begin{tabular}{|c|c|c|}
\hline & Frequency & $\%$ \\
\hline \multicolumn{3}{|l|}{ Age: (years) } \\
\hline$<30$ & 36 & 22.6 \\
\hline $30-<40$ & 61 & 38.4 \\
\hline$\geq 40$ & 62 & 39.0 \\
\hline Mean \pm SD & \multicolumn{2}{|c|}{$38.22 \pm 10.02$} \\
\hline \multicolumn{3}{|l|}{ Experience: (years) } \\
\hline$<5$ & 57 & 35.8 \\
\hline $5-10$ & 44 & 27.7 \\
\hline$>10$ & 58 & 36.5 \\
\hline Mean \pm SD & \multicolumn{2}{|c|}{$10.33 \pm 8.58$} \\
\hline \multicolumn{3}{|l|}{ Unit/department } \\
\hline Special surgery & 84 & 52.8 \\
\hline General surgery & 26 & 16.3 \\
\hline Private Wards & 33 & 20.8 \\
\hline Incinerator & 7 & 4.4 \\
\hline Waste collection room & 9 & 5.7 \\
\hline \multicolumn{3}{|l|}{ Education: } \\
\hline Illiterate & 76 & 47.8 \\
\hline Read/write & 61 & 38.4 \\
\hline Preparatory & 13 & 8.2 \\
\hline Secondary school & 9 & 5.7 \\
\hline \multicolumn{3}{|c|}{ Attended training in waste management } \\
\hline Yes & 7 & 4.4 \\
\hline No & 152 & 95.6 \\
\hline
\end{tabular}

Table (2): Distribution of housekeepers' report practices and preventive measures throughout intervention at Main Assiut University Hospital (2016).

\begin{tabular}{|l|c|c|}
\hline \multicolumn{2}{|c|}{ No. $(\mathbf{n}=\mathbf{1 5 9})$} & $\%$ \\
\hline Expose to needle stick : & \multicolumn{2}{|c|}{} \\
\hline Yes & 106 & 66.7 \\
\hline No & 53 & 33.3 \\
\hline If yes: Manage sharp injury: (n= 106) & \multicolumn{2}{|c|}{} \\
\hline Correct & 11 & 10.4 \\
\hline Incorrect & 95 & 89.6 \\
\hline Notificate and fill incidence report about sharp injury: $(\mathrm{n}=106)$ & \multicolumn{2}{|c}{} \\
\hline Yes & 3 & 2.8 \\
\hline No & 103 & 97.2 \\
\hline Immunization against HBV: & \multicolumn{2}{|c}{} \\
\hline Yes & 66 & 41.5 \\
\hline No & 93 & 58.5 \\
\hline
\end{tabular}




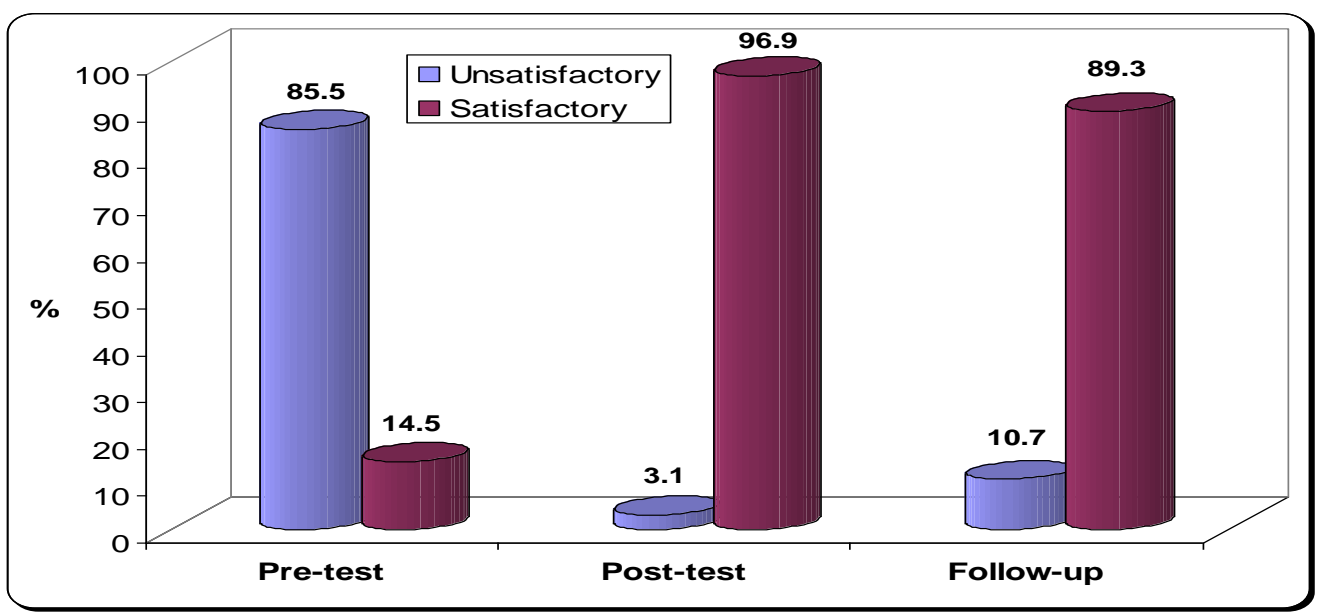

P1

$(0.000 *)$

P2

$(0.000 *)$

Fig (1) : Distribution of housekeepers' total score knowledge regarding safe health care of hospital waste in pre , immediate post and follow up at Main Assiut University Hospital (2016)

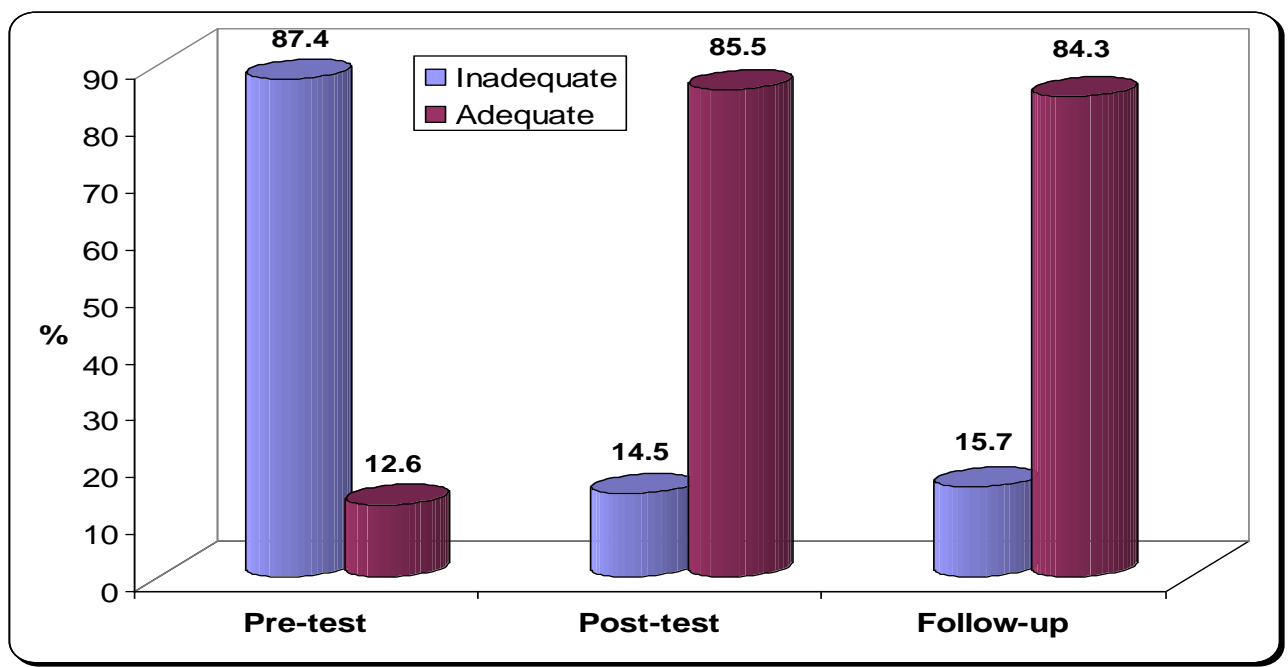

P1 $(0.000 *)$

P2 (0.000*)

Fig 2 : Distribution of housekeepers' total score practices regarding health care waste management in pre, immediate post and follow up at Main Assiut University Hospital(2016)

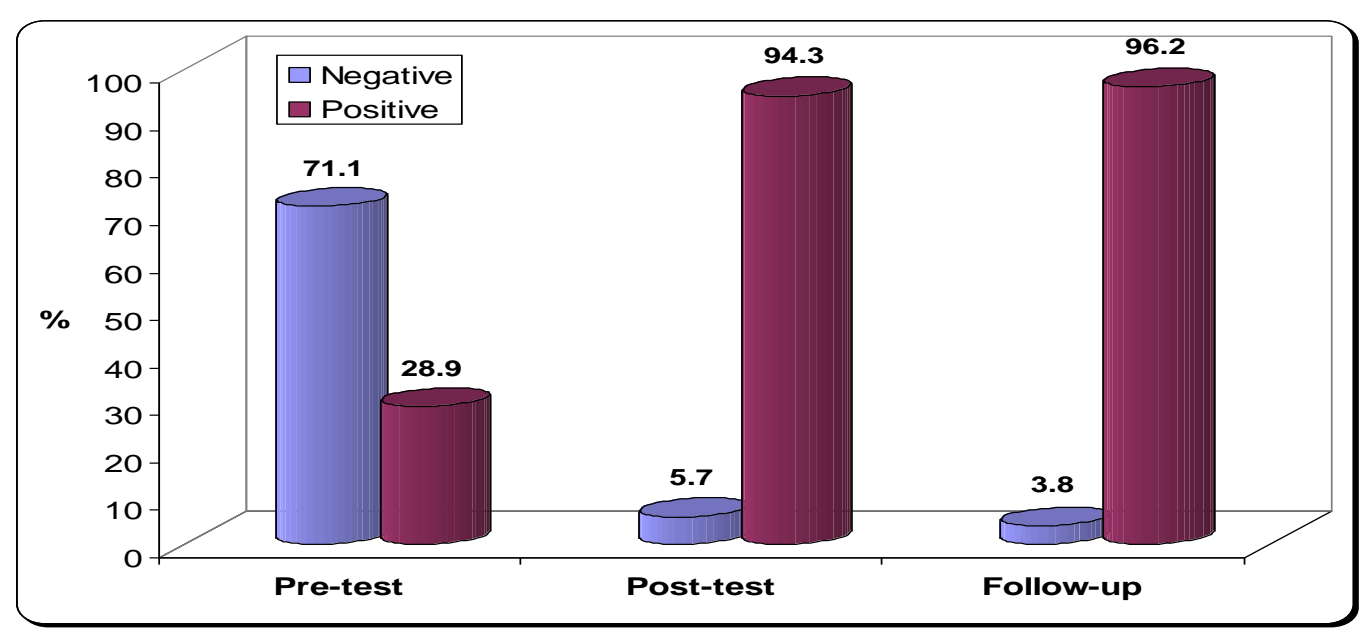

P1 (0.000*)

P2 $(0.000 *)$

Fig (3) : Distribution of housekeepers' total score attitude in pre, immediate post and follow regarding at Main Assiut University Hospital(2016) 
Table(3): Correlation of housekeepers' knowledge, attitude, and practice scores with age and years of experience.

\begin{tabular}{|l|c|c|c|c|}
\hline \multirow{2}{*}{} & \multicolumn{2}{|c|}{ Age (years) } & \multicolumn{2}{c|}{ Years of experience } \\
\cline { 2 - 5 } & r-value & P-value & r-value & P-value \\
\hline Knowledge & 0.041 & 0.610 & 0.007 & 0.934 \\
\hline Attitude & 0.028 & 0.728 & 0.059 & 0.462 \\
\hline Practices & $\mathbf{0 . 3 1 7}$ & $\mathbf{0 . 0 0 0}$ & $\mathbf{0 . 2 5 9}$ & $\mathbf{0 . 0 0 1}$ \\
\hline
\end{tabular}

(*) statistically significant at $p<0.05$.

Table (1): Illustrates the distribution of the housekeepers regarding their Personnel characteristics. It was found that $39.0 \%$ of the study sample had aged $\geq 40$ years. Concerning their experiences it was found that $36.5 \%$ had more than 10 years of experiences. About $52.8 \%$ of study sample from special surgery departments. $47.8 \%$ of the study sample were illiterate. While $95.6 \%$ of study sample had not attended training about waste.

Table (2): shows that $\mathbf{6 6 . 7 \%}$ were exposed to needle stick. While only $10.4 \%$ know the action in sharp injury. Regarding to the incidence report about sharp injury $97.2 \%$ didn't report . $41.5 \%$ received immunization .

Figure (1) : This figure characterizes total score of housekeepers' knowledge regarding health care of hospital waste in pre, post, and follow-up test. It was initiate that there is highly statistical significant difference between pretest and posttest $\mathrm{p}_{1}=\left(0.000^{*}\right)$, The same finding exists between pretest and follow up test after the insevice training program $\mathrm{p}_{2}=$ $(0.000 *)$.

Figure(2): This figure shows that: Most of housekeepers had adequate practice as regard Postfollow up with percentage $(85.5 \%$ and $84.3 \%$ respectively) with highly statically difference $\mathrm{p}$ value $(0.000 *)$.

Figure(3): This figure describes housekeepers' attitude toward health care waste management throughout the training program before the program the housekeepers had negative attitude with percent about less than one third

and this percentage has declined to only $5.7 \%$ immediately after implementation of the program and 3.8 in the follow up. Meanwhile at Post-Fu time nearly all of housekeepers had positive attitude towards waste management with percentage $94.3 \%$ and $96.2 \%$ respectively. with p-value $=0.000 *$

Table (3): This table illustrates the positive correlation between houskeepers scores of knowledge, atittude ,practices with age and years of experience adjusted for the effect of training program. It indicates that only statistically significant correlations revealed were between practices with age and years of experience with $\mathrm{p}=\left(0.000^{*}\right.$ and $0.001^{*}$ respectively). Both of these correlation were weak positive $r=(0.317$ and 0.259 respectively $)$

\section{Discussion}

Hospital waste is a special type of waste produced in small quantities carrying a high potential of infection and injury. Inadequate and improper handling may have serious public health values and a major impact on the environment. It is important that they have adequate knowledge about the importance of segregation and how to distinguish the different containers and bins for the various types of health care waste, the health hazard of hospital waste, proper technique and methods of handling the waste, and practice of safety measures can go a long way toward the safe disposal of hazardous hospital waste and protect them, their patients, as well as the communities and the environment Jerie, (2016).

As regards pesonnel characteristics of the studied sample the most of study group had aged $\geq 40$ years . These results agreed with Asha \& Tukaram, (2014) who conducted a study about assessment of effectiveness of educational intervention on knowledge among bio-Medical waste handlers in Krishna Hospital India.They reported that more than one third of biomedical waste handlers have been in the age group between 46 to 59 years.

More than one third from the current study had more than 10 years of experiences .These results disagreed with Rakesh et al., (2010) who conducted a study about knowledge and awareness regarding needle stick injuries among health care workers in Tertiary care hospital in Ahmed abad Gujarat. They founded more than three fifths of the subjects had been working as health care workers for less than 5 years. In the present study more than half of study group from special surgery department. Nearly half of the study group is illiterate. The vast majority of study group had not attended training about waste management because there limited number of housekeepers in the hospital. So it is difficult to leave work to attend any training program, this results is in the line with study of Mustafa et al., (2008) who implemented their study in Helwan hospital,Egypt. the result revealed that the majority of the health care workers had not attended any training related to 
waste management program or conference. Moreover (WHO, 2005) advised that proper training and education must be offered to all workers from doctors to ward personnel, and most health workers require the same basic set of skills, knowledge and attitudes towards good waste management. These training programs should take into consideration the level of education of the housekeepers.

As regard to incidence of sharp injures the finding of current study revealed that two third of studied sample had previous expsoure of injuries with sharps or needle sticks during application of their duties because poor handling or disposal of used needles, recapping needles, inappropriate use of a punctureproof container may be attributed to lack of awareness about the size of acquiring occupational disease and disposing of the waste generated in the healthcare setting by incineration. The present study is in agreement with Gamal, (2011) who conducted a study about assessment of knowledge and practices of housekeepers regarding safe handling of hospital waste at Assiut University Hospital, Egypt.Who found that half of the exposures occurred during activities such as cleaning instruments and disposal or handling of waste. Inappropriate disposal of sharp items continues to put healthcare workers at risk, particularly housekeepers' .

In the present study more than two fifth of the studied sample received vaccine against hepatitis $B$ virus due to central system defect. Also the present study disagree with the finding of Blenkharn, (2011) who mentioned that fifteen individuals for whom vaccination status was unknown received hepatitis B immunoglobulin at Oxford University .While this result is in disagreement with Gamal, 2011 who found that more than two third of housekeepers had been vaccinated for HBV which explain high level of awareness of housekeepers about importance of vaccination.

As regard to the fill incidence report about sharp injury in the current study the vast majority from sample identifies the important of recording because the housekeeping staff were not alert by the importance of reporting, this finding is in agreement with Madhukumar \& Ramesh, (2012) who conducted a study about awareness and practices about health care wastes management among hospital staff in a medical college hospital, Bangalore, Iranian. Who found that no staff ever reported any injury to the Medical causality, medical officer which would have occurred due to unsuitably disposed waste. However, needle stick injuries were reported by the housekeeping staff and attenders when questioned in detail during the study period. The housekeeping staff did not feel it was important to report such injuries and some were not aware of the hazards associated with it.

Regarding housekeeper's knowledge about infection control the researchers found that the studied sample had poor knowledge about meaning of infection, hospital acquired infection, importance of hand washing and hand disinfection in pretest due to absence of in-service education program, and they improved in post and follow up tests. These results were in similarity with Elnour, (2015) who carried out study in Sudan at White Nile State main hospitals about Impacts of health education on knowledge and practice of hospital staff with regard to Health care waste management. Who mentioned that there was a significant improvement in knowledge after the educational intervention program, with the participants showing good knowledge more than two third immediately and after three months. Also the present study found that the studied sample had poor knowledge about waste management in the hospital,or from incinerator because open burning poses a risk to workers due to the chemical exposure to heavy metals and halogenated hydrocarbons, namely, dioxins and furan, that are generated from the combustion of biomedical waste. These pollutants may directly affect the housekeepers and the community.The poor knowledge of housekeepers may be due to absence of in-service training program in the hospital. These results supported by Madhukumar \& Ramesh, (2012) who Study about awareness and practices about health care wastes management among hospital staff in a medical college hospital, Bangalore. Iranian .Who found housekeepers were less knowledgeable about specific details of disposal. colour coding and waste segregation.

The present study revealed highly significant improvement in housekeepers knowledge total score about safe health care of hospital waste management $(p=0.000 *)$. The proportion of housekeepers showing satisfactory knowledge rise from less one quarter before intervention to the vast majority immediately and to the vast majority after three months of the intervention program. The improvement in knowledge scores indicates that the program had a very good outcome. This may be due to the content of the educational intervention program; the written handouts distributed during the program. The finding of the present study was in agreement with

El-Sharkawy, (2009) study in Zagazig University Hospital in Egypt in where an educational program about health care waste management was implemented. The present study also revealed significant improvement in nurses and housekeepers knowledge, with the proportion having good knowledge rising from one quarter before 
intervention to more than two third after implementing the intervention program. The present study agree with Ajai \& Nath (2013) who stated that satisfactory knowledge, attitude and practices .This has significantly improved after implementing of the program in the immediate post-program and in the follow-up tests. This improvement indicates that the program succeed in raising the scores of this items of knowledge \& reflects the desirable effect of the program, though at the follow up test and This may be due to the content of the educational intervention program;the written handouts distributed during the program, which serve as reference.

The findings of the present study showed that most housekeepers had inadequate practices about handwashing, infection control and safe handling of hospital waste before the implementation of the educational training program. This findings could be explained by unavailability of appropriate technologies, inadequate finances and a lack of waste management training programs, lack of supervision, lack of incentive for safe waste management, housekeepers do not believe biomedical waste management as an important qualification for a good patient care service, some also felt that this is not their duty and that biomedical waste management is the responsibility of the administration. After the implementation of the in-service program, there were significant improvements with the most of housekeepers who achieved adequate score in the post and follow-up. This is most likely due to the effect of the educational program. These findings agree with Shafee et al., (2010) study conducted in India about Knowledge, Attitude and Practices Regarding Biomedical waste amongst workers. Showed that found more than two third of the housekeeping practiced waste management. The process of segregation, collection, transport, storage and final disposal of infectious waste was done in compliance with the standard procedures. It was also found that the non-infectious waste was collected separately indifferent containers and treated as general waste. Regarding intermediate storage, The present study findings showed the adequate practice score of the housekeepers before, post and follow up the intervention of the program because there is special place in the hospital for storage waste and there system in the hospital the present study disagree with Elnour, (2015) mentioned that poor practice score in nearly two third of the participants for healthcare waste storage before the intervention program, and this result did not improve after the intervention.

Concerning hand washing practice after collection and segregation the majority of the housekeepers showed good practices after implementation program.
The finding of the present study was consistent with El-Sayed et al., (2012) study conducted in Egypt about Intervention Program for Nurses and sanitation staff about Health Care Waste Management . Reported a low percentage of nursing and sanitation staff washing their hands. Potter \& Perry, (2016) (Fundamentals of Nursing) mentioned that hand washing is the most basic and effective infection control measure that prevents and controls the transmission of infectious agents, and that barrier precautions are also used to minimize the risk of exposure to blood and body fluids.

Meanwhile, the wearing uniform and personnel protective equipment hard work gloves and boats there change from pre, post and follow up because in the follow up increase the number of housekeepers wearing personnel protective equipment's and the researcher talks with the administrator about the defect of personnel protective equipment and encourage housekeepers to use a protective barriers. Also Put symbol the name of the department on the collected bags highly improvement from pre and post to the vast majorty in the follow because there is new director for Environmental Affairs in Assiut University hospital. And she put system for coding collected bags.This finding disagrees with Rasheed et al., (2005) who found most of unsanitary waste storage areas in Iran the segregation of biomedical waste is poor. Generally inefficient packaging, labeling, transportation and storage increases the health and safety risks to healthcare personnel. Regarding the attitude of housekeepers about hand washing is important. Working in the hospital expose to infection,Separated of waste its responsibility for all health team work and Correct separation of waste provide budget to the hospital the researcher found that the studied sample had negative attitude in pretest and improvement in the post and follow up nearly all of housekeepers had positive attitude towards waste management in post test and follow up three months later. This result in the line with Fayaz, (2014) who mentioned that the attitude of healthcare workers towards waste disposal at hospital, he was found that, overall, more housekeeping staff had satisfactory attitude .This is disagree with the present study disagree with (Mohamed \& Wafa, 2011) from Bangalore the study conducted about The Effects of an Educational Program on Nurses Knowledge and Practice Related to Hepatitis C Virus who showed that the nurses had significantly more positive attitudes compared with technicians and housekeeping staff.

Pre, post and follow up tests scores is highly statistically significant difference this shows that the in-service program about health care Waste management is very effective. Similar finding are 
seen in Basarkar, (2014) in his study which conduct in Mumbai about Structured Training key to Successful Bio-medical Waste Management in Hospital they reveled statistically significant difference was found among workers who received training of bio-medical waste management which is evident from the rise level of knowledge. While in Fayaz et al., (2014) the healthcare workers in Kabul in Afghanistan about Knowledge and practice of universal precautions among health care workers in four national hospitals had inadequate knowledge and poor practice in applying universal precautions. The inadequate knowledge and the improper practice could be related to many factors such as lack of periodic training and supervision, and lack of perceived seriousness of the negative outcomes this finding agree with the present study.

\section{Conclusions}

According to results and research hypothesis it found that ,there were marked improvements in housekeepers' knowledge, attitude and practices immediately after implementation of the training program. This improvement was mostly retained after three month, with slight decline, particularly related to knowledge, although still higher compared to preimplementation level. Strong correlations were revealed among housekeepers' knowledge, attitude and practices scores.

\section{Recommendations}

1- Periodic in-service training program for all housekeepers about safe handling, storage, treatment, and disposal.

2- Periodic medical check up for all housekeepers working in the hospital.

3- Housekeepers should be sure vaccinated against viral hepatitis B.

4- Occcupational Safety and Health or infection control unit should be kept post exposure incident report in the medical file and follow up.

Future more than research about In-service training

Program for Housekeepers regarding Safe Health

Care Waste Management at Main Assiut University

Hospital

\section{References}

1. Abu Salam M., Anwar El-Shazly H., Dewidar M., (2014):Infection control awareness among healthcare providers in family health settings in Shebin El-kom district, Menoufia Governorate, Egypt. Menoufia Med J Vol.27.No(6):p $\mathrm{p}_{\mathrm{p}} 840$.

2. Ajai, S., \& Nath, S., (2013): Knowledge, attitude and practices of bio-medical waste management amongst staff of institutional trauma center level II. International Journal of Research in Health
Sciences (Supplement) July-Sept, Vol.1 No(2):PP.67-68

3. Arora, L., \& Agarwal, S., (2011). Knowledge, attitude and practices regarding waste management in selected hostel students of university of Rajasthan, Jaipur. Int $\mathrm{J}$ Chem Environ Pharm Res, Vol.2 No.(1):pp.40-43.

4. Asha P., Tukaram Z., \& Satish V., (2016): "Effectiveness of Educational Intervention on Practice among Biomedical Waste Handlers"International Journal of science and ResearchVol. 3 Issue 8,: pp.1885 to1891.

5. Bansal, M., Mishra, A., Gautam, P., Changulani, R., Srivastava, D., \& Gour, N., (2011): Biomedical waste management: awareness and practices in a district of Madhya Pradesh. Natl J Commun Med, Vol.2.No(3):pp. 453-6.

6. Basarkar S., (2014): Structured Training key to Successful Bio-medical Waste Management in Hospital. Curr World Environ.;Vol.9.No(1):pp.123-129.

7. Blenkharn J., (2011): Clinical waste management. Encyclopedia of Environmental Health. Elsevier Science, Philadelphia, USA.

8. Elnour, A., Moussa, M., El-Borgy, M., Fadelella, N., \& Mahmoud, A., (2015): Impacts of health education on knowledge and practice of hospital staff with regard to Healthcare waste management at White Nile State main hospitals, Sudan. International journal of health sciences, Vol.9.No.(3):pp.

9. El-Sayed S., Zakaria A., Gheith N., (2012): Intervention Program for Nurses about Health Care Waste Management. Research Journal of Medicine and Medical Sciences. Vol.7:pp:25-37.

10. El-Sharkawy G., (2009): Effect of an Educational Program about Medical waste Management on Awareness of Internship Physicians in Zagazig university Hospitals. Zagazig Journal of Occupational Health and Safety;Vol.2:p p.10-6.

11. Fayaz S., Higuchi M., Hirosawa T., Sarker M., Djabbarova Z., Hamajima N., (2014): Knowledge and practice of universal precautions among health care workers in four national hospitals in Kabul, Afghanistan. J Infect Dev Ctries Vol.15;8.NO(4):PP.535-

12. Gamal N., (2011): Assessment of knowledge and practices of housekeepers regarding safe handling of hospital waste at Assiut University Hospital.Master thesis Faculty of Nursing.

13. Hakim A., Mohsen \& I., Bakr, (2014): Knowledge, attitudes and practices of health-care personnel towards waste disposal management at Ain Shams University Hospitals, Cairo. 
14. Hossain M., Santhanam A., Norulaini N., \& Omar A., (2011): Clinical solid waste management practices and its impact on human health and environment: A review. Journal of Waste management, Vol 31:pp. 754-766. http:// who..theific.org/basicconcepts/ppt_pdf/18.pdf

15. Ioos S., Mallet H., GoffartL. Gauthier V., Cardoso T., \& Herida M., (2014): Current Zika virus epidemiology and recent epidemics. Medecine et maladies infectieuses, "Current Zika virus epidemiology Medecine et maladies infectieuses, and recent epidemics Medecine et maladies infectieusesand recent epidemics vol.44.No(7): $\mathrm{p}_{\mathrm{p}} 302-307$.

16. Jerie S., (2016): Occupational risks associated with solid waste management in the informal sector of Gweru, Zimbabwe. Journal of environmental and public health.vol. 5. No.( 1): pp. 46-64.

17. Koren, H., (2017): Best Practices for Environmental Health: Environmental Pollution, Protection, Quality and Sustainability, CRC Press.

18. Lugendo, M., (2014): Strengthening Garden Mazingira Group on household waste collection services: A case study of Mwananyamala in Kinondoni municipality, Dar es Salaam, The Open University of Tanzania.

19. MadhaviK. Reddy B., \& Ravikumar B., (2013): Awareness regarding biomedical waste management among interns in a tertiary health care hospital, Khammam.J. Evol. Med. Dental Sci. 2(29): 5360-5365

20. Madhukumar, S., \& Ramesh, G., (2012): Study about awareness and practices about health care wastes management among hospital staff in a medical college hospital, Bangalore. Iranian Journal of Basic Medical Sciences, 3(1), 7-11.

21. Manish Patidar, Pavan Kumar Jain \& Ravindra H., (2014): Effec-tiveness of Structured Teaching Programme on Bio-Medical Waste Management. IOSR-JNHS. 3(3):60-5.

22. Landelle, C., Pagani, L., \& Harbarth, S., (2013): Is patient isolation the single most important measure to prevent the spread of multidrug-resistant pathogens?. Virulence, Vol. 4.No(2): $p_{p}$. 163-171.

23. Mohamed S., \&Wafa A., (2011): The Effects of an Educational Program on Nurses Knowledge and Practice Related to Hepatitis C Virus: A Pretest and Posttest Quasi-Experimental Design. Australian Journal of Basic and Applied Sciences 5(11):564-70.

24. Mostafa, G., Shazly \& Sherief, (2008): Development of Waste Management Protocol Based on Assessment of Knowledge and practice of Healthcare Personnel in Surgical Departments.
Waste Management, 29(1): 430-439. http://www.ncbi.nlm.nih.gov/pubmed/18316184

25. Potter P., Perry A., (2016): Fundamentals of Nursing; 7th edition; Mosby Elsevier;.

26. Rakesh Shah, H., Mehta, Manish Fancy, Sunil Nayak, \& Bhavesh N., Donga (2010): :knowledge and awareness regarding needle stick injuries among health care workers in Tertiary care hospital in Ahmedabad, Gujarat. National Journal of Community Medicine;1,2: 93-97

27. Shafee, M., Kasturwar \& N., Nirupama, (2010): Study of Knowledge, Attitude and Practices Regarding Biomedical Waste among Paramedical Workers. Indian J. Community Med., 35(2): 369-37

28. World Health Organization (WHO),(2005): Basic concept of infection Health care waste management. Available at from: www.who.int/whr/2008/en/whr02_ch4.pdf 